\title{
Kant, Proust, and the Appeal of Beauty
}

\section{Citation}

Moran, Richard. 2012. Kant, Proust, and the appeal of beauty. Critical Inquiry 38(2): 398-329.

\section{Published Version}

doi:10.1086/662744

\section{Permanent link}

http://nrs.harvard.edu/urn-3:HUL.InstRepos:8920788

\section{Terms of Use}

This article was downloaded from Harvard University's DASH repository, and is made available under the terms and conditions applicable to Other Posted Material, as set forth at http:// nrs.harvard.edu/urn-3:HUL.InstRepos:dash.current.terms-of-use\#LAA

\section{Share Your Story}

The Harvard community has made this article openly available.

Please share how this access benefits you. Submit a story.

\section{Accessibility}




\title{
Kant, Proust, and the Appeal of Beauty
}

\author{
Richard Moran
}

1

A familiar feature of the history of modern aesthetics is the cycle of suspicion and defensiveness connected with the idea of beauty, as though its very appearance suggested something exaggerated, something requiring deflation, which then provokes a certain polemical stance on the part of both its defenders and detractors. People who would not be tempted by a reductive account of other concepts (for example, of thought, or desire, or action), may still feel that beauty has to be shown to be illusory or explained as a mere guise of some other force or quality altogether in the end. One might, for instance, have reasons to be suspicious of pleasure itself, its role in culture, or the exaggerated claims for it, or one may have metaphysical scruples deriving from the idea that beauty can be no property of things in themselves but can only be a projection of our own sensibilities upon the world. In different ways, then, there can seem to be a certain extravagance built into the notion of the beautiful itself, as though it were internal to its invocation that it claims more for itself than it can deliver on. Familiar as these thoughts are, however, their import is far from clear. The thought about projection, for instance, need not be any more skeptical than the parallel claims that are made about secondary qualities generally, the supervenience of which on our sensory dispositions is not

I had the pleasure of presenting some of this material at a Warren Quinn Conference at the University of California, Los Angeles, where I benefitted from comments by Franklin Bruno; at a Sawyer Seminar at the University of Chicago, hosted by David Wellbery and James Conant; in a series of seminars at Johns Hopkins University hosted by Michael Fried; at a workshop on philosophy and literature and film organized by Susan Wolf at the University of North Carolina, Chapel Hill; and at the New York University Conference on Modern Philosophy and Aesthetic Judgment, organized by Beatrice Longuenesse, John Richardson, and Don Garett, where I had helpful comments from Rebecca Kukla. The paper benefitted from all these occasions, particularly from the hosts in question, as well as from audiences at the University of Illinois, University of Chicago, Stanford University, and the University of Illinois, UrbanaChampaign. For conversations either on those occasions or much earlier I am grateful to Stanley Cavell, Fred Neuhouser, Alexander Nehamas, Paul Guyer, Jonathan Lear, Lanier Anderson, Joshua Landy, Katalin Makkai, Meredith Williams, Robert Pippin, Wayne Martin, Brent Kalar, Michael Williams, Hannah Ginsborg, Katalin Makkai, Thomas Teufel, Melissa Merritt, Tim Scanlon, and David Sussman.

At early stages of the project conversations with Martin Stone helped orient me in the topic, and toward the end of it conversations with Arata Hamawaki were crucial to giving shape to the story.

The paper is dedicated to the memory of Mary Mothersill. 
usually taken to be equivalent to their being simply unreal or to be incompatible with the idea that in calling the sky blue one is claiming something beyond one's subjective experience. ${ }^{1}$

The idea of beauty, however, can lend itself to repudiation of another kind, as being a perfectly useless concept, the residue of pieties we can no longer take seriously. And in the life of an individual, something in the idea of beauty makes possible its characteristic forms of disillusion and not merely disappointment. One may be disappointed with one's experience of ordinary pleasures, finding in them less than one hoped to find or even losing one's taste altogether for certain of them. In relation to beauty, however, there is room for the possibility of not just disappointed expectations but disillusionment and, with that, repudiation of the very idea of beauty, as though the very idea were a form of mystification. What I take this to show is that the very possibility of such skepticism is testament to the fact that there is something additional it would make sense to reject in the claim of beauty, something beyond the thought that something is a special source of pleasure. It is only against the background of something supposedly beyond ordinary pleasure and pain that there is the possibility of rejecting its claim, finding it perhaps quaint or hollow. With regard to beauty, there seems to be room for a different kind of rejection of its reality or genuineness

1. Consider this well-known passage:

Attend to Palladio and Perrault, while they explain all the parts and proportions of a pillar. They talk of the cornice, and frieze, and base, and entablature, and shaft, and architrave; and give the description and position of each of these members. But should you ask the description and position of its beauty, they would readily reply, that the beauty is not in any of the parts or members of a pillar, but results from the whole, when that complicated figure is presented to an intelligent mind, susceptible to those finer sensations. Till such a spectator appear, there is nothing but a figure of such particular dimensions and proportions: from his sentiments alone arise its elegance and beauty. [David Hume, An Inquiry into the Principles of Morals (Middlesex, 2006), p. 81]

Here Hume seems to derive a claim about the subjectivity of beauty from the common fact of the constitution of one set of properties by another. Palladio could just as rightly say that the strength of the pillar is not in any of its parts or members, but it would hardly follow from this that its strength was somehow unreal or a mere projection of the sentiments.

Richard Moran is the Brian D. Young Professor of Philosophy at Harvard University. He is the author of Authority and Estrangement: An essay on selfknowledge. He is completing Self-Expression and the Modes of Address, a book on intersubjectivity in the acts of speaking and telling. 
or the thought that it can't be and never was all that it presents itself as being. ${ }^{2}$

There is, however, another related set of reasons why the concept of beauty is subject to forms of skepticism peculiar to it. Far more than most other concepts of philosophical interest the idea of beauty has a welldeveloped cultural mythology that is as much a part of it as are any theories of it that have been proposed. Indeed, the competing philosophical theories themselves have little point taken in isolation from the various depictions of the encounter with beauty that make their appearance throughout the Western tradition, from Plato to the Christian era, through romanticism, modernism, and whatever comes after that. Part of what I mean by mythology is that these ideas are something like a common cultural resource, that they inform our actual experience and thinking about the thing in question, and are for that reason to be seen as belonging to the concept itself, whether part of its literal or figurative content. There needn't be anything elaborate in such depictions, so let me begin with some simple examples, neither original nor exhaustive. So, for instance, beauty is commonly associated with mystery, as something that beckons but also withdraws and withholds, something whose nature belongs with appearing but that also presents itself as containing in itself more than is apparent. While it belongs to the sensory, to the realm of feeling, and is in that sense fully present to experience, at the same time it partakes of concealment in ways not shared by the rest of sensory life. A familiar trope of beauty is that of something not just pointing beyond itself but as harboring a secret or posing a question to be answered. And this is itself one of the classic settings for the disappointment and disillusion associated with beauty. A running theme in Marcel Proust's Swann's Way, for instance, is the repeated frustration of the narrator in his attempts to penetrate the secret that seems to be held by the scenes he finds most enthralling, which seem to pose a question that he cannot formulate, let alone answer. ${ }^{3}$

The beautiful not only beckons but also charms, enthralls, and other-

2. Or compare beauty with ordinary pleasure and pain with regard to the possibility of error. Given the appearance of pleasure or pain, it is hard to imagine a place for a further question about its genuineness or reality. Given the appearance of beauty, we may later come to question its genuineness or reality and perhaps come to the conclusion that the appearance of beauty here was a false one. It didn't hold up to scrutiny; its promise was false or meretricious. If this is right, then beauty, unlike pain or pleasure, is not a property whose esse is percepi. And it raises the question of what sort of scrutiny it is that could show that an apparent beauty was in fact false, or what further question that appearance would have to answer to show itself to be real. (Kant, of course, takes up such questions in terms of the conditions for a pure judgment of taste.)

3. Here he is, early in the story, after one of his recurrent moments of despair of ever being equal to his literary vocation: 
wise captivates its beholder. The tradition of describing something beautiful in such grammatically active aesthetic verbs as compelling, enticing, or appealing is both part of ordinary speech and a way of depicting the encounter with the beautiful object as somehow two-sided, involving an active element on the side of the object itself to which the beholder actively responds. This can be a perfectly anodyne way of talking, of course, and the metaphorical residue thoroughly effaced and without force, but even as dead metaphor such discourse registers a difference from other responsedispositional concepts, such as red, and highlights the idea of a type of response that the beautiful object calls for or makes appropriate. Whether we think of the active verbs in this context as simply dead metaphors or as the result of projection on the part of the beholder, their presence also suggests a difference in the kind of response the beholder may feel obliged to summon in the face of the object, a responsiveness of a different kind from that involved in making correct color judgments. Along the same lines, though less anodyne, the use of such active aesthetic vocabulary applied to the object belongs to the tradition of seeing something animated or animating in the experience of the beautiful or in the actual thing found beautiful. ${ }^{4}$ Here again, Immanuel Kant is no stranger to this tradition, both in the association of beauty with the arousal of the "quickening" powers of the mind (most especially and obscurely the "free play of the cognitive powers [imagination and understanding]") and more generally in the con-

\footnotetext{
Then, quite independently of all these literary preoccupations and in no way connected with them, suddenly a roof, a gleam of sunlight on a stone, the smell of a path would make me stop still, to enjoy the special pleasure that each of them gave me, and also because they appeared to be concealing, beyond what my eyes could see, something which they invited me to come and take, but which, despite all my efforts, I never managed to discover. Since I felt that this something was to be found in them, I would stand there, motionless, looking, breathing, endeavouring to penetrate with my mind beyond the thing seen or smelt. [Marcel Proust, Swann's Way, trans. C. K. Scott Moncrieff and Terence Kilmartin (New York, 1992), pp. 251-52; hereafter abbreviated $S W]$
}

4. "In this glum desert, suddenly a specific photograph reaches me; it animates me, and I animate it. So that is how I must name the attraction which makes it exist: an animation (Roland Barthes, Camera Lucida: Reflections on Photography, trans. Richard Howard [London, 1981], p. 20). The connection of beauty with the ideas of life-likeness and animation is thematic in Elaine Scarry's On Beauty and Being Just and is part of her account of the thought that the beautiful object calls for certain forms of treatment, the way a living thing would: "The almost aliveness of a beautiful object makes its abrasive handling almost unthinkable" (Elaine Scarry, On Beauty and Being Just [Princeton, N.J., 2001], p. 69; see also pp. 89-93, 110). 
nections drawn between beauty and the purposive in living nature, between aesthetic and teleological judgment. ${ }^{5}$

In many canonical representations, the encounter with beauty takes place against the background of its transience and perishability. "Death is the mother of beauty," Wallace Stevens says at the end of "Sunday Morning," ${ }^{\text {" }}$ and in this he is giving voice to a long tradition of thinking of beauty alongside its relation to time and destruction, which is also part of thinking of it as essentially fleeting, eluding one's grasp, impossible to possess. Pleasures quite generally may be fleeting, but talk of beauty makes it almost a sign of its own relation to death, either as submitting to it or promising to outlast it. This is connected with the sense of the special possibilities of damage there are with respect to beauty: it not only fades, like other pleasures, but is also the sort of thing that can be defaced or disfigured. Beauty is subject to the possibility of ruin and not just interruption or decline. The characteristic relation of beauty to special possibilities of loss expresses itself both in the association of beauty with ideas of irreplaceability, taking beauty out of the ordinary economy of exchange and substitution (and hence toward the possibility of absolute, unrecoverable loss), and also to the tradition of thinking of the experience of beauty as promising to defeat death or defeat time somehow. That is, beauty also figures in the guise of something redeeming or compensating for the finitude or perishability of other values, particularly as contrasted with other pleasures. This part of the myth of beauty is surely part of what is repudiated in some of the forms of skepticism about beauty mentioned earlier, the thought that the sheer contingent existence of beauty in the world somehow makes up for other failings or losses or shows them to be less real than beauty itself.7 In their very different ways, both Kant and Proust take the improbable appearance of beauty in our experience of the world as requiring explanation in terms of something else, as pointing to either our fitness for moral life and the world's possible conformity to moral good, as in Kant, or, as a kind of liberation from subjectivity in Proust, from the natural solipsism of desire as appetite.

Finally, both in philosophy and elsewhere, beauty is associated with enhanced stakes for the question of the communicability of experience,

5. Immanuel Kant, Critique of Judgment, trans. Werner S. Pluhar (Indianapolis, 2000), \$9, pp. 63, 62; hereafter abbreviated CJ.

6. Wallace Stevens, "Sunday Morning," Selected Poems, ed. John N. Serio (New York, 2009), p. 44.

7. For a sophisticated critique of the redemptive claims of art, rather than beauty generally, see Leo Bersani, “'The Culture of Redemption': Marcel Proust and Melanie Klein,” Critical Inquiry 12 (Winter 1986): 399-421. 
not only as problematizing such communication but as making more urgent the question of how much can be communicated one to another and the situations in which its success can be peculiarly fraught or urgent. Beauty may lay no exclusive claim to the idea of the ineffable in experience, but it is surely central to it, and this thought relates beauty both to difficulties in the notion of communication itself, to the incurably private in experience, and to the specific needs of the shareability of experience that arise in aesthetic contexts. The issue of communication includes but is not restricted to the question of finding we agree in our particular aesthetic judgments and also includes the conditions for various forms of disagreement. The relation to beauty can form communities of people and can also isolate them from each other. Nothing is more characteristic of the aesthetic than being bored or repelled by what enthralls someone else. And if being gripped by beauty can sometimes make possible certain forms of communication that were not previously imagined, it also belongs to its experience to tend toward obsession, absorption, and the walling-off of one consciousness from others. ${ }^{8}$

While his systematic, critical concerns dictate much of the place that aesthetic judgment occupies in his philosophy, Kant is in one way or another responsive to all of this and more in the broader myth of beauty, and several of his central claims can be understood as attempts to render parts of it intelligible in more abstract and systematic terms. (The place of beauty in Kant's philosophy is in these ways part of but not restricted to what he is responding to in romanticism.) Here I will be concentrating on his framing of the central paradox of the judgment of beauty, how it is that something based on the purely subjective experience of pleasure and without the support of concepts or rules could claim universal validity for itself. While this paper does present itself as an interpretation of a central strain in Kant's account of the judgment of beauty, there is much in his argument to which I will give scant attention (particularly the role of transcendental psychology and the "freeplay of the faculties"); and in addition I will argue for departures from his account at some central places, so central that some may wonder how much of Kant remains in the story. The point of reading Kant in connection with Proust has not been simply to use the novelist as a corrective to the philosopher, although the paper is indeed written from the perspective that it should be beyond question that Marcel Proust is at least as decisive a thinker about the nature of beauty as is

8. See especially Stanley Cavell, "Aesthetic Problems of Modern Philosophy," Must We Mean What We Say? A Book of Essays (Cambridge, 1976), and Arata Hamawaki, "Kant on Beauty and the Normative Force of Feeling," Philosophical Topics 34 (Spring-Fall 2006): 107-44. 
Immanuel Kant. It is just as much the point, however, that Proust can help us to see what is deeply right, or nearly so, in Kant's outlook, as well as what Kant wants from the concept of beauty, even if it can't be had exclusively from the materials he allows himself.

\section{2}

A judgment of taste determines its object in respect of our liking (beauty), [but] makes a claim [Anspruch] to everyone's assent, as if it were an objective judgment.

To say, This flower is beautiful, is tantamount to a mere repetition of the flower's own claim [Anspruch] to everyone's liking. The agreeableness of its smell, on the other hand, gives it no claims [Ansprüche] whatever; its smell delights ... one person, it makes another dizzy. In view of this ... must we not suppose that beauty has to be considered a property of the flower itself, which does not adapt itself to differences in people's heads and all their senses, but to which they must adapt themselves if they wish to pass judgment on it? [CJ, \$32, p. 145; trans. mod.]

Sagen: diese Blume ist schön, heisst eben so viel, als ihren eigenen Anspruch auf jedermanns Wohlgefallen ihr nur nachsagen.

Anspruch: claim, title, right, demand.

ansprechen: speak to, accost, address, appeal to.

ansprechend: pleasing, attractive, appealing, engaging.

Many writers on aesthetics recognize a special question about the normativity of the judgment of beauty, insofar as this is different from the judgment of something as agreeable or pleasant. In a familiar sense there is a normative dimension to any empirical judgment, in that there are conditions for going right or going wrong, and if one is in the business of making such judgments one is obliged to conform one's judgment to the conditions of correctness. This much applies to the judgment of something as red as much as it does to judging it beautiful. But although we can specify the conditions necessary for someone to be in a position to make a correct color judgment (adequate or normal lighting, attending carefully enough, and so on), they do not, as it were, commend anyone to get themselves into those conditions. The world is full of opportunities for correct empirical judgments to which we may be legitimately indifferent. And the 
red or square objects around us are not awarded that title as a term of praise or admiration. The idea of beauty, however, according to Kant and much of the tradition, does not simply specify the conditions one must satisfy in order to make such a judgment correctly but also involves the claim that the object in question merits this response, that it deserves one's attention and that anyone attending to it properly ought to respond with pleasure and admiration. These are dimensions of normative assessment that are not part of the concept of an object's being red or square. The idea of beauty may well contain conditions for correct judgment, just as there are with the judgment of color (and Kant has his well-known specifications of these in terms of disinterest, attention to form, and so on), but these do not exhaust the normative dimension of the judgment of beauty. For with regard to beauty the idea of the object meriting or calling for a response from us seems to be what is primary, a norm of responsiveness that is prior to the obligation the response shares with ordinary empirical judgments of conforming to certain conditions for correct judgment. And any particular form of normative requirement-whether moral, prudential, or cognitive-brings its own particular possibilities of falling short, of failure to conform to its own demands.

Both Kant and Proust are concerned with a sense of requirement or obligation in connection with the experience of the beautiful and see this as the primary difference between the beautiful and the (merely) agreeable or pleasant. For Kant, the requirement is described as something directed outwards, toward other people, in that we speak of the beautiful as such only when we are not speaking merely for ourselves but are prepared to demand the agreement of all others.

Many things may be charming and agreeable to him; no one cares about that. But if he proclaims something to be beautiful, then he requires the same liking from others; he then judges not just for himself but for everyone, and speaks of beauty as if it were a property of things. That is why he says: The thing is beautiful, and does not count on other people to agree with his judgment of liking on the ground that he has repeatedly found them agreeing with him; rather he demands [fordern] that they agree. He reproaches them if they judge differently, and denies that they have taste, which he nevertheless demands of them, as something they ought to have. [ $C J$, \$7, pp. 55-56]

The language here couldn't be more emphatic as to its imperatival quality, but insofar as the demand in question is a demand to others (however hypothetical their presence) that they agree in liking the beautiful object, it raises the question of what the basis could be for such a demand, what 
there is in this demand that another person might be bound to respect. That is, what could it be that places this person in a position to issue such a demand? It cannot be simply his personal authority, a possibility that Kant in any case is at great pains to reject. Rather, it would seem that, as with the issuing of moral or prudential demands, the person is in a position to make such a demand only because he recognizes himself as subject to a requirement here, to be under an obligation. The source of the outwarddirected requirement on others in these cases can only be his own acknowledgment of the obligations of the moral law or the maxims of practical reason. But in the case of someone prepared to require the agreement of all others in his liking or pleasure in connection with something he finds beautiful, it is difficult to see what could ground his own sense of requirement or obligation with respect to that thing such that it could be the basis for the imperative he directs to others. ${ }^{9}$

In one sense this question of the normative force of this demand directed to others is not a problem for Proust; he does not understand the beautiful in terms of a demand for universal agreement and in fact is more inclined to relate the validity of the claim of the beautiful to what is individualizing and even potentially isolating in such an experience. But if he does not have to face the question of what the source of the demand for agreement from others could be, he does at the same time insist on a sense of obligation or requirement as characteristic of the experience of the beautiful. Here is the young Marcel, early in the story, saying goodbye to his beloved hawthorns, whose claim on him he will retain through all the volumes of In Search of Lost Time.

That year my family fixed the day of their return to Paris rather earlier than usual. On the morning of our departure ... my mother, after searching everywhere for me, found me standing in tears on the steep little path close to Tansonville, bidding farewell to my hawthorns, clasping their sharp branches in my arms.... "Oh, my poor little hawthorns," I was assuring them through my sobs, "it isn't you who want to make me unhappy, to force me to leave you. You, you've

9. Kant uses a variety of terms to express the sense of something required or exacted in the judgment of beauty. The verbs that get variously translated as "require," "demand," and so on include fordern, verlangen, ansinnen ("We must begin by fully convincing ourselves that in making a judgment of taste [about the beautiful] we require [ansinnen] everyone to like the object" [CJ, \$214, p. 57] and zumuten ("For as to the agreeable we allow everyone to be of a mind of his own, no one requiring [zumuten] others to agree with his judgment of taste. But in a judgment of taste about beauty we always require others to agree” [CJ, \$214, p. 57]). See Paul Guyer, Kant and the Claims of Taste (Cambridge, Mass., 1997), pp. 123-30 for a helpful discussion. I have also been instructed on this topic by a conversation with Rolf-Peter Horstmann, for which I am grateful. 
never done me any harm. So I shall always love you." And, drying my eyes, I promised them . . I I would never copy the foolish example of other men, but that even in Paris, on fine spring days, instead of paying calls and listening to silly talk, I would set off for the country to see the first hawthorn-trees in bloom. [SW, pp. 203-4]

So declares the narrator, whom for our purposes we may call Marcel, and naturally he breaks this promise to the hawthorns quite soon, and thousands of pages later he is still absorbed with paying calls in Paris and listening to silly talk. That isn't the end of the story, of course, and in his own way and in his own sweet time he remains faithful to his hawthorns, in the writing and remembering itself and their constant return to Combray. Encounters and declarations like this one to the hawthorns are the beginnings of his vocation as a writer. In this passage and others in Proust, we have a representative expression of the experience of beauty, and indeed much of the rest of the long novel is about his efforts and failures to keep faith with his early formative experiences of the beautiful. ${ }^{10}$ But to say even this much is already to risk losing critical perspective and speak from rather than about the consciousness of young Marcel; for, really, what sense could there possibly be in "keeping faith" with anything like a bunch of hawthorn trees in bloom, however beautiful, as if one could have obligations of some sort with respect to them? Well, for that matter, how is it that he takes himself to be addressing the hawthorns in the first place, bidding farewell, making to them a declaration of love, promising them to come see them again?

For all the appearance of excessiveness in this passage (the mode of excess being Proust's own), it stands as a representative expression of the

10. To underscore that Proust is indeed describing an aesthetic encounter here, I refer to his introduction to this scene eight pages earlier, where the language is unmistakable:

And then I returned to the hawthorns, and stood before them as one stands before those masterpieces of painting which, one imagines, one will be better able to "take in" when one has looked away for a moment at something else; but in vain did I make a screen with my hands, the better to concentrate upon the flowers, the feeling they aroused in me remained obscure and vague, struggling and failing to free itself, to float across and become one with the flowers. They themselves offered me no enlightenment, and I could not call upon any other flowers to satisfy this mysterious longing. And then, inspiring me with that rapture which we feel on seeing a work by our favorite painter quite different from any of those that we already know, or, better still, when we are shown a painting of which we have hitherto seen no more than a pencilled sketch, or when a piece of music which we have heard only on the piano appears to us later clothed in all the colours of the orchestra, my grandfather called me to him, and, pointing to the Tansonville hedge, said to me: "You're fond of hawthorns; just look at this pink one-isn't it lovely?" [SW, p. 195] 
experience of beauty, even in its indulgence in language and attitudes normally reserved for our relations with other persons. We often speak of the beautiful in terms of something appealing to us or demanding of our attention, and the pleasure we may experience in something beautiful raises the issue of its calling for that pleasure or that attention, in a way that does not apply to other things that may arrest our attention or gratify our senses. Even the highly strung, overemotional Marcel does not talk this way about the pleasures of eating or drinking, however discriminating his palate and however fine-grained his attention to experience. The things we consume, however intense their pleasures may be, raise no questions of something that might be betrayed or kept faith with, a claim or a call that might be answered or ignored. If there really is a difference between what Kant calls the pleasure in the beautiful and the pleasure in the agreeable, this is not a difference in the degrees of pleasure taken, for the pleasure in the beautiful itself can be something faint or flickering, while the experience of the merely agreeable can itself be overpowering. Rather than a difference in the quality or intensity of pleasure, the distinction Kant has in mind is a difference in attitude we take toward something we consider beautiful and consequently a difference in the type of judgment one is prepared to make on behalf of the thing we find beautiful—or so I shall argue. More specifically, I hope to show that Kant's emphasis on the demand for universal agreement to distinguish the judgment of the beautiful from the judgment of the agreeable is not in fact primary but is derived from a prior sense of necessity or demand that characterizes the experience of the beautiful itself. In short, universal agreement doesn't always matter (aesthetics and ethics are not one), but the sense of the beautiful making a claim upon us does, and this much is derivable from Kant's initial distinction between the beautiful and the agreeable.

The agreeableness of Canary wine and the beauty of a landscape or a work of art are both given expression in what Kant calls a judgment of taste. Both types of judgment of taste are based on a feeling of pleasure (or displeasure) and hence are subjective in the sense of denoting nothing in the object itself, not simply because the judgment is based on sensation, but more specifically because the particular sensation of pleasure is simply of the wrong sort to be a possible property of the object itself. Neither type of judgment is based on concepts or reasoned to as the conclusion of some inference or argument but instead depends on one's own direct experience of the thing in question. As a consequence, neither kind of judgment of taste can be made on the authority of someone else's report or grounded in another person's judgment or testimony. 
The fact that others have liked something can never serve him as a basis for an aesthetic judgment. If others make a judgment that is unfavorable to us, this may rightly make us wonder about our own judgment, but it can never convince us that ours in incorrect. Hence there is no empirical basis of proof that could compel anyone to make [some] judgment of taste.

Second, still less can a judgment about beauty be determined by an a priori proof, in accordance with determinate rules....

It seems that this is one of the main reasons why this aesthetic power of judging was given that very name: taste. For even if someone lists all the ingredients of a dish, pointing out that I have always found each of them agreeable, and goes on to praise this food—and rightly so- as wholesome, I shall be deaf to all these reasons: I shall try the dish on $m y$ tongue and palate, and thereby (and not by universal principles) make my judgment. [CJ, \$33, pp. 147-48]

This is one dimension of the judgment of taste that Kant refers to under the title of autonomy. Under this aspect the judgment of taste is independent of both the judgments of other people and the rational determination of concepts. It may be that "as a rule" I do like foods of a certain kind, a kind that is determined by the applicability of certain concepts, but I can be disappointed in my expectations here and fail to find pleasure where I usually do. And more importantly, Kant argues, there is nothing in the normative aspect of a rule that obliges me to take pleasure in something I find not to my liking, even if I agree that it fits the description of the kind of thing that as a rule I do like. Logical or conceptual inconsistency has no grip here; there is nothing that would oblige me to bring my tastes into line with what is suggested by the concept or description of the thing in question. The normative center of gravity lies in one's own direct experience of the thing, what Kant calls apprehensio, and it cannot be overruled either by the concepts that the thing falls under or by the testimony of others.

In the "On the Method of the Deduction and Judgments of Taste," Kant sums up this feature of the judgment of taste in the following way:

its universal validity is not to be established by gathering votes and asking other people what kind of sensation they are having; but it must rest, as it were, on an autonomy of the subject who is making a judgment about the feeling of pleasure ... i.e., it must rest on his own taste; and yet it is also not to be derived from concepts. [CJ, $\$_{31}$, p. 144] 
Moreover, whenever a subject offers a judgment as proof of his taste... we demand that he judge for himself: he should not have to grope about among other people's judgments by means of experience, to gain instruction in advance from whether they like or dislike that object.... That is why a young poet cannot be brought to abandon his persuasion that his poem is beautiful, neither by the judgment of his audience nor by that of his friends.... Taste lays claim merely to $a u$ tonomy; but to make other people's judgments the basis determining one’s own would be heteronomy. [CJ, \$32, pp. 145-46; my emphasis]

At first glance, there is undoubtedly something arresting in Kant of all people using the term autonomy to describe a context of judgment that is independent of the determination of rules or principles. Surely it is Kant who has shown most forcefully that freedom cannot be understood as anything like the mere absence of all constraint or principle (empirical or normative), for that would abolish the distinction between acting and being acted upon. ${ }^{11}$ Rather, the very idea of acting freely means acting for some reason, which means acting in conformity with a law or principle that one gives oneself, which is what autonomy means. For now, let's just note this as a stress that the Kantian idea of autonomy is subjected to early in the analysis of the judgment of taste. More immediately, I want to point out that this sense of the autonomy of the judgment of taste applies equally to the agreeable as to the beautiful. That is to say, neither one's judgment about the Canary wine nor one's judgment about the beautiful song or beautiful scene are normatively determined by principles or conceptual requirements, but can only be grounded in one's own apprehensio of the thing in question. This is important to bear in mind, for Kant also speaks of freedom and autonomy in characterizing the specific difference between the judgment of the agreeable and the judgment of the beautiful. This latter sense of autonomy is related to a sense of obligation that applies only to the pleasure in the beautiful and not the agreeableness of the Canary wine. The pleasure or displeasure taken in the Canary wine may not be compelled by rational or conceptual requirements, but this pleasure surely is compelled by something else, namely, the force of inclination, desire, and need. Our relation to the agreeable is determined by and in the service of our character as needy human animals, whereas the pure judgment of taste, the experience of something as beautiful, is independent both of our more basic biological inclinations and of the rational interests to which they give

11. See in particular Kant, "Transition from the Metaphysics of Morals to the Critique of Pure Practical Reason," Groundwork of the Metaphysics of Morals, trans. Mary Gregor (Cambridge, 1997), pp. 52-66. 
rise. In this way, the pleasure in the agreeable is a pleasure that is essentially in bondage. As a form of valuation, it possesses no independent validity of its own, for it is in the service of other, previously given ends with respect to which we are passive. For Kant, a liking or a taking pleasure in something that is an expression of our freedom is only possible when its conditions are independent not only of conceptual determination but also of determination by any desire or interest we may happen to bring to the experience.

His liking is not based on any inclination he has ... rather, the judging person feels completely free as regards the liking he accords the object. [CJ, \$6, p. 54]

We may say that, of all these three kinds of liking, only the liking involved in the taste for the beautiful is disinterested and free, since we are not compelled to give our approval by any interest, whether of sense or of reason. So we might say that [the term] liking, in the three cases mentioned, refers to inclination, or to favor [Gunst], or to respect. For FAVOR is the only free liking. Neither an object of inclination, nor one that a law of reason enjoins on us as an object of desire, leaves us the freedom to make an object of pleasure for ourselves out of something or other. [CJ, \$5, p. 52]

Thus, both the judgment of the agreeable and the judgment of the beautiful are free and autonomous with respect to both conceptual requirements and the judgments of other people. But the pure aesthetic judgment, the judgment of something as beautiful is also free in an additional sense, in that it is disinterested, that is, free from the compulsion or determination of desire, interest, or need. Thus, the famous Kantian insistence on the disinterestedness of the judgment of beauty as the primary feature distinguishing it from the judgment of the agreeable is an aspect of what he calls the freedom of the pure judgment of taste. The pleasure in the beautiful is autonomous in the sense of answering only to itself and its own conditions, and not to those of any antecedent desire or interest we may have.

\section{3}

This aspect of the autonomy belonging to the judgment of the beautiful is the expression of a difference in the attitude we take toward the objects we find beautiful, as contrasted with the things we find agreeable, gratifying, or the contrary. The beautiful is something that indeed gives pleasure, but we do not relate to it as something that simply answers to our purposes, 
something to be consumed, used up, and disposed of. This thought has sources more ancient than Kant and a varied afterlife as well. Simone Weil, for instance, strikes a characteristic note of self-denial when she says, "the beautiful is a carnal attraction which keeps us at a distance and implies a renunciation.... We want to eat all the other objects of desire. The beautiful is that which we desire without wishing to eat it. We desire that it should be." ${ }^{12}$ But what is renounced in the experience of the beautiful (as contrasted with the agreeable) is not desire or gratification themselves; rather it is the authority and force of one's presently constituted desires and interests, which are instead to be given over to and guided by the confrontation with something outside them, independent of them. Here preservation is contrasted with consumption, and we can see here the primal distinction Kant is appealing to between what we take inside and incorporate and what we stand before and behold. We might also say: We stand back from the beautiful, as with an object of respect or as with something displayed or held in regard, whereas the agreeable is something we pick up, consume, and forget about. G. W. F. Hegel is explicitly responding to Kant in his Introductory Lectures on Aesthetics and stages the encounter of desiring consciousness with the world in terms of the same opposition between what is taken inside and thus destroyed, and what is encountered within the world and thus preserved. In so doing he pursues further the relation between what is autonomous in the judgment of beauty and what is autonomous in the beautiful itself:

In this appetitive relation to the outer world, the man stands as a sensuous particular over against the things as likewise particulars ... and preserves himself in them, inasmuch as he uses them, consumes them, and puts in act his self-satisfaction by sacrificing them to it... . Just as little is it possible for desire to let the object subsist in its freedom. For its impulse urges it just precisely to destroy this independence and freedom of external things, and to show that they are only there to be destroyed and consumed. But, at the same time, the subject himself, as entangled in the particular limited and valueless interests of his desires, is neither free in himself, for he does not determine himself out of the essential universality and rationality of his will, nor free in relation to the outer world, for his desire remains essentially determined by things and related to them. This relation of desire is not that in which man stands to the work of art. He allows it to sub-

12. Simone Weil, "Beauty," The Simone Weil Reader, ed. George A. Panichas (Wakefield, R.I., 1977), p. 378. 
sist as an object, free and independent, and enters into relation with it apart from desire. ${ }^{13}$

What the criterion of disinterestedness means in Kant is that the beautiful object is something that is liked for its own sake and not just insofar as it answers to our antecedent needs, desires, and interests. The immediately striking thing in Hegel's language is that he describes the situation as though the idea of liking an object "for its own sake" meant not simply liking noninstrumentally (which in one sense would apply to the relation to the agreeable as much as to the beautiful) but also as though the beautiful thing ${ }^{14}$ had an independent life of its own to which we had to adapt ourselves. For here and elsewhere he writes not only of the freedom in the conditions of the judgment of the beautiful (freedom from determination by desire and interest) but also of the freedom of the beautiful object itself-something in it, therefore, that we may respect or fail to respect. And yet, for all the extravagance of his language here, Hegel is giving expression to an idea that recurs in the history of aesthetics, the sense that what is regarded as beautiful is not experienced as a passive thing or as something that merely produces an effect in us but rather as inviting or requiring something from us, a response that may be owed to it. ${ }^{15}$ And in fact in this Hegel is responding to a central feature of Kant's view of what is distinctive about the beautiful that has not yet entered our account here, which is the necessity that applies to the pleasure in the beautiful as contrasted with that of the agreeable. The Fourth Moment of the Analytic of the Beautiful, on the modality of the pure judgment of taste, is summed up by Kant in saying, "Beauty is what without a concept is cognized [erkannt] as the object of a necessary liking" ( $C J, \$ 62$, p. 240). Without yet inquiring how there could be such objects of necessary liking, and necessary for whom, we can see that the freedom or autonomy of the pleasure in the beautiful (its independence from desire or interest) must somehow be the ground of a necessity in the response to the beautiful, for neither this au-

13. G. W. F. Hegel, Introductory Lectures on Aesthetics, trans. Bernard Bosanquet, ed. Michael Inwood (London, 1993), p. 41.

14. Or more properly, the work of art, for here Hegel departs significantly from Kant in giving primacy to artistic beauty over natural beauty.

15. Here is Ludwig Wittgenstein, complaining about the language of producing effects, in connection with aesthetic matters, with the implication that the work of art is an instrumental means to an antecedent end or need: "There is a tendency to talk about 'the effect of a work of art'-feelings, images, etc. Then it is natural to ask: 'Why do you hear this minuet?' and there is a tendency to answer: 'To get this and that effect.' And doesn't the minuet itself matter?- - Hearing this, would another have done as well?" (Ludwig Wittgenstein, Lectures and Conversations on Aesthetics, Psychology, and Religious Belief, ed. Cyril Barrett [Maldon, Mass., 1966], p. 29). 
tonomy nor any necessity at all applies to the pleasure taken in the merely agreeable. And it is this aspect of the pure judgment of taste that allows for the particular normativity in responding to the beautiful, something we may respect or fail to respect, a normativity that does not apply either to the pleasure of the agreeable or to ordinary empirical judgments such as those of color.

The necessity attaching to the response to the beautiful that distinguishes it from the response to the merely agreeable is reflected in the sense of requirement or demand that, for Kant, is the fundamental difference between the judgment of the taste of reflection, which applies to what we find beautiful, and the taste of sense, which applies to what we find agreeable or gratifying. For, according to Kant, the defining difference of the judgment of the beautiful is that, despite its independence of the requirements of concepts or principles, it nonetheless lays claim to universal validity. When speaking of something I find pleasant or agreeable, I am content to speak merely for myself and simply say that I like it, but if I am prepared to call something beautiful it is part of the very meaning of the judgment I mean to express that I present myself as speaking with what Kant calls a universal voice. ${ }^{16}$ This universal voice has the character of a demand for or a requirement of the same liking or favoring from others. So fundamental is this difference that Kant claims it would never occur to anyone to speak of beauty in the first place, rather than speak indifferently of any source of pleasure (without a concept), unless we intended this requirement of universal assent to our judgment.

We must begin by fully convincing ourselves that in making a judgment of taste (about the beautiful) we require [ansinnen] everyone to like the object, yet without this liking's being based on a concept (since then it would be the good), and that this claim to universal validity belongs so essentially to a judgment by which we declare something to be beautiful that it would not occur to anyone to use this term without thinking of universal validity; instead, everything we like without a concept would then be included with the agreeable. For as to the agreeable we allow everyone to be of a mind of his own,

16. Cavell's "Aesthetic Problems of Modern Philosophy" is still the best introduction to Kant's idea of speaking with a universal voice. As will be seen, I think that actual universality is the wrong direction for the communication of the judgment of beauty, but elsewhere in that same essay Cavell makes the connection between aesthetic experience and communities smaller than that of universal humanity, between myself and others of my flesh, as he likes to say. The community that matters for the communicability and validity of a judgment of taste is less like universal humanity and more like a circle of intimates, fans, fellow enthusiasts. See also Hamawaki, "Kant on Beauty and the Normative Force of Feeling." 
no one requiring [zumuten] others to agree with his judgment of taste. But in a judgment of taste about beauty we always require others to agree. [CJ, \$8, p. 57]

To underscore that the person making such a judgment is making a normative demand and not simply declaring his expectation that he is judging in accord with general humanity, Kant favors a strongly imperatival language to describe the stance assumed by the judgment of beauty. In making such a judgment, we "requir[e] others to agree," we demand (fordern) that they like it as we do, even: "we permit no one to hold a different opinion" (CJ, \$22, p. 89). ${ }^{17}$ But to speak in any of these ways raises the question of what could be the basis for such a requirement, and why agreement should matter in this way to the person who finds something beautiful, when for the most part it doesn't matter that other people find the Canary wine delightful as he does? ${ }^{28}$ What could be the source of such a demand? And given that judgments of the agreeable and of the beautiful are both judgments of taste, and hence involve a freedom that is not enjoyed by ordinary empirical judgments, Kant's insistence on an imperatival aspect of the judgment of beauty creates problems for how the participants in such a dialogue understand what they are doing. For recall that a judgment of the beautiful is free in the dual sense of not being determined by a concept of the thing (as is a judgment of something as good, by contrast) and also not determined by any interest, desire, or need (as is a judgment of something as agreeable). Thus, Kant puts it, "only the liking involved in the taste for the beautiful is disinterested and free, since we are not compelled to give our approvalby any interest, whether of sense or of reason" ( $\left.C J, \$_{5}, \mathrm{p} .52\right)$. Just as the person judging something to be beau-

17. On this circle of terms, see footnote 9 here. Guyer's causal interpretation of the judgment of taste favors a rendering according to which what is claimed in the judgment is that all others will agree with it, subject to the proper conditions for the making of such judgments. As such his view downplays the explicitly normative language in Kant in terms of the demand for agreement in favor of a factual reading in terms of the prediction of agreement. For support of the normative understanding of Kant's language here, Hannah Ginsborg writes: "The translation thus suggests, in a way that the original does not, that the claim to universal agreement is factual rather than normative: more specifically, that it is a prediction that others will agree with our judgment (at least under appropriate circumstances) rather than a strong normative claim that they ought to agree with it. This is in fact Guyer's view, but it is a controversial one" (Hannah Ginsborg, "Critique of the Power of Judgment," Philosophical Review 111 [July 2002]: 431-32). Henry E. Allison also insists on the normative reading in his dialogue with Guyer; see Rebecca Kukla, Aesthetics and Cognition in Kant's Critical Philosophy [Cambridge, 2006], p. 132), and Henry E. Allison, Kant's Theory of Taste: A Reading of the Critique of Aesthetic Judgment (Cambridge, 2001), pp. 104, 130.

18. Indeed, one might think, if they don't share my good opinion of it, that just means more Canary wine for me. 
tiful recognizes that he is not compelled by reason, interest, or desire to acknowledge this thing as beautiful, he must recognize that if others are to so much as understand the kind of judgment he is making they must acknowledge themselves as similarly free with respect to it. This is demanded by the concept itself. And yet in announcing the judgment of beauty he expresses himself in terms apparently denying the freedom of others to judge otherwise ("we permit no one to hold a different opinion"). Here stands the aesthetic subject, confidently declaring something to be beautiful, and thereby requiring the agreement of everyone else, when by his own admission he can offer them neither reasons nor inducements to comply with this demand. And this is so not because of any inability of his, because he has not succeeded in finding the right kinds of reasons or inducements, but rather because of the very nature of the kind of claim he is trying to make. Because it is a judgment of beauty (and not, for example, of goodness or pleasantness) he must both require universal agreement and at the same time divest himself of any reliance on the authority, reasons, principles, threats, or bribes that could bring his audience to comply with his requirement. And, indeed if he somehow managed to secure agreement in any of these ways, this could only mean that he has been misunderstood by his audience and perhaps that they simply lacked the concept of the beautiful altogether (and hence could not really know to what they agree).

If his audience does not lack the concept of the beautiful, and therefore understands the condition of the autonomy of aesthetic judgment, they will not simply be disinclined to agree with the speaker, to accede to his demand for agreement, on the basis of his reasons or his authority. Rather they will take themselves to be obliged to dismiss anyone who seeks to compel agreement in such a way, and this will be in virtue of their understanding of the autonomy of the very kind of judgment being presented to them. This is not obstinacy on their part but an appreciation of the logic of the concept in question. And, indeed, Kant presents just a scene for us:

If someone reads me his poem, or takes me to a play that in the end I simply cannot find to my taste, then let him adduce Batteaux or Lessing to prove that his poem is beautiful ... moreover, let certain passages that I happen to dislike conform quite well to rules of beauty (as laid down by these critics and universally recognized): I shall stop my ears, shall refuse to listen to reasons and arguments, and shall sooner assume that those rules of the critics are false, or at least do not apply in the present case, than allow my judgment to be determined by a 
priori bases of proof; for it is meant to be a judgment of taste, and not one of the understanding or of reason. [CJ, \$33, p. 148]

Hence, if this is how both parties to the discussion understand the autonomy of the judgment of taste, this seems to present the spectacle of one person obliged by the nature of the kind of judgment he means to make to express it in terms requiring the agreement of all others, while at the same time knowing that his audience finds itself equally under the obligation, given the nature of the judgment in question, to stop their ears and refuse to listen. The speaker takes himself to be expressing a perfectly free liking, a liking that is in fact free in an additional sense to the freedom of an ordinary expression of pleasure in the agreeable. As Kant says, we recognize the freedom of the taste of sense in the attitude of "allow[ing] everyone to be of a mind of his own, no one requiring [zumuten] others to agree with his judgment of taste. But in a judgment of taste about beauty we always require others to agree" ( $C J, \$ 8, \mathrm{p} .57)$. What is strange in this is that, as we saw, the taste of reflection (judgment of beauty) enjoys the same freedom as does the ordinary taste of sense and in addition to that is also free in a way that is not enjoyed by the taste of sense, yet the result seems to be a restriction on the freedom that is granted to the ordinary judgment of the agreeable. What we seem to have here, then, is a perfectly free liking of my own that I nonetheless require of all others. What could ground such a requirement when it is itself the expression of a liking, a favoring, that is characterized as beyond (or before) all requirements?

\section{4}

Beauty is causally linked with pleasure and inspires love.... Plato's psychology is more accurate than Kant's: our earliest impressionand in that sense our prototype of beauty-is not a wildflower but a human face, one that is the focus of intense if ambivalent affect. ${ }^{19}$

Or perhaps what all this suggests is that the liking, the favoring in question is not in fact experienced by the person as outside the bounds of all requirements or obligations after all. If we return to Proust I think we can see the case for preserving a sense of necessity or requirement as a defining difference in the experience of the beautiful but one that obliges us to separate the sense of necessity or requirement in the encounter from the demand for universal agreement. In this way we can begin to see the aesthetic subject as something other than an overbearing person who seeks to

19. Mary Mothersill, Beauty Restored (Oxford 1984), pp. 271, 273. 
impose on others what is for him a perfectly free liking, inventing a requirement out of something that is for himself free of all requirements.

To begin with, not every sense of requirement is universal in form, and the obligations we feel to certain people, places, or other objects of love are often such that we can find it impossible even to explain them to another person, let alone to justify to them in such a way that they could come to find themselves under the same obligation themselves. Nor would seeking such agreement always seem to the point or add any missing validation to the experience or sense of a claim upon oneself. The necessity experienced and lived out in one's relation to a person or a vocation does not translate into a desire for or even the possibility of universal agreement. Obligations and their necessities can come singly and individualize or even isolate the person who finds himself subject to one. ${ }^{20}$ We saw something of this in the young Marcel's tearful farewell to his hawthorns, his declaration of love to them, and his promise to keep faith with them. Proust is hardly the first writer to be occupied with the relations between the demands of love and the appeal of beauty, but there may be no one who is more insistent on figuring the experience of the beautiful itself in explicitly intersubjective terms (being called to, summoned, or addressed), as if the sense of demand associated with the beautiful required nothing less. As with the experience of the beautiful itself, this can take more or less extreme forms and need not progress to the extremes of making promises or declarations of love. The experience of the beautiful is not always dramatic or even particularly intense, and the idea in question is about the category of judgment to which the beautiful belongs, not the degree of intensity in its experience. But Proust wants something from the distinction between the beautiful and the agreeable that Kant also wants, something that is not a difference in degree of intensity but a difference of logical category, which would account for a specific sense of requirement in the experience of what we regard as beautiful that does not apply to our other sources of gratification. The various sources of gratification exist for us in terms of answering to our needs and are valued according to how well they perform this service. But something we are prepared to call beautiful is not measured purely by its ability to satisfy our given desires but is rather something to which our

20. And as in Harry G. Frankfurt's discussion of the volitional necessities of love, the thought is not that love itself is demanded or required but that loving something or someone creates necessities for the person, marking out the limits of what can coherently be willed, creating obligations of responsiveness and attention. See Harry G. Frankfurt, The Reasons of Love (Princeton, N.J., 2004) and Necessity, Volition, and Love (Cambridge, 1998). I discuss the relations of love and necessity in Richard Moran, "The Reasons of Love by Frankfurt," review of The Reasons of Love by Frankfurt, Philosophy and Phenomenological Research 74 (Mar. 2007): $463-75$. 
pleasure or desires themselves may be answerable, to which they may need to conform themselves, or by which they may be instructed. This much, I would claim, follows from Kant's original distinction between the agreeable and the beautiful. And we can put the same point in more explicitly Proustian terms by relating it to his great theme of disappointment. For it is when we are prepared to call something beautiful that there is now logical room not simply for disappointment in one's experience, as there might be with respect to any hoped-for source of pleasure, but for disappointment in oneself rather than in the object, for the various possibilities of failure of responsiveness. With respect to the hawthorns, Marcel makes a vow that he soon breaks but later makes good on. Later in the story, with respect to the shifting views of three trees that he sees at evening from a moving coach, he takes this structure of normativity to what is even for Proust remarkable extremes, incorporating several of the strands from beauty's mythology that we have seen before.

I looked at the three trees; I could see them plainly, but my mind felt that they were concealing something which it could not grasp, as when an object is placed out of our reach.

Did they conceal beneath their surface, like the trees, like the tufts of grass that I had seen beside the Guermantes way, a meaning as obscure, as hard to grasp, as is a distant past, so that, whereas they were inviting me to prove a new thought, I imagined that I had to identify an old memory? Or again, were they concealing no hidden thought, and was it simply visual fatigue that made me see them double in time as one sometimes sees double in space? I could not tell. ... I chose rather to believe that they were phantoms of the past, dear companions of my childhood, vanished friends who were invoking our common memories. Like ghosts they seemed to be appealing to me to take them with me, to bring them back to life. In their simple and passionate gesticulation I could discern the helpless anguish of a beloved person who has lost the power of speech, and feels that he will never be able to say to us what he wishes to say and we can never guess. Presently, at a cross-roads, the carriage left them. It was bearing me away from what alone I believed to be true, what would have made me truly happy; it was like my life.

I watched the trees gradually recede, waving their despairing arms, seeming to say to me: "What you fail to learn from us today, you will never know. If you allow us to drop back into the hollow of this road from which we sought to raise ourselves up to you, a whole part of 
yourself which we were bringing to you will fall for ever into thin air." And indeed if, in the course of time, I did discover the kind of pleasure and disquiet which I had felt once again, and if one evening- too late, but then for all time-I fastened myself to it, of those trees themselves I was never to know what they had been trying to give me nor where else I had seen them. And when, the road having forked and the carriage with it, I turned my back on them and ceased to see them, while Mme de Villeparisis asked me what I was dreaming about, I was as wretched as if I had just lost a dear friend, had died myself, had broken faith with the dead or repudiated a God. ${ }^{21}$

Even by Proust's own exalted standards, the language here is extreme in its depiction of the experience of being captivated, and its very extremity helps to make visible a more general idea of norms of responsiveness that have some claim to define the idea of the beautiful as such. And, as mentioned earlier, with any distinct form of normativity there will be distinct possibilities for violation of the norm or failure to conform to its demands. The young Marcel breaks his promise to the hawthorns early on but makes good on it later. In this passage the forms of normative failure are figured in terms of the threat of betrayal, fearing that one's own response will turn out to have been one of faithlessness or heedlessness, the failure to answer some question posed to oneself alone, and thus the threat of loss of self or of the possibility of one's genuine life. There is a demand here, surely, but it is not a demand for universal agreement. Rather, it is something whose consummation would require him to be alone. And in the reference to "the helpless anguish of a beloved person who has lost the power of speech" there is even a proleptic allusion to the death of the most beloved person in the book, Marcel's grandmother, who does indeed lose the power of speech, and the delayed response to whose death, several volumes later, is the occasion of one of the great cataclysms of his life, an eruption of the past and the self-reproach for his failures of responsiveness in the present both when she was alive and for a full year after her death.

While I have been emphasizing the strain in Kant's account, stemming from his insistence on the universal imperatival character of the judgment of beauty, he does himself appeal to the necessities of love to characterize the specific modality that distinguishes the pleasure of the beautiful from the pleasure of the agreeable. His formulation, "the beautiful prepares us for loving something, even nature, without interest; the sublime, for esteeming it even against our interest (of sense)" (CJ, \$29, p. 127), expresses

21. Proust, Within a Budding Grove, trans. Moncrieff and Kilmartin (New York, 1992), pp. 405, 408; hereafter abbreviated $B G$. 
the competing side of his thinking that aligns him with a tradition of thinking about beauty that goes back at least as far as Sappho. It provides one way to make out the necessity Kant insists on in the judgment of the beautiful without the need to assimilate it to a demand for universal agreement or to subsume the specific normativity of the beautiful to that of morality. There are wilder and more measured experiences of the beautiful, after all, and the form of normative requirement in a given case need not take the dramatic forms described by Proust. We only need to hold onto the sense that it belongs to the beautiful but not to the agreeable and that there can be types of responses or ways of treating the thing that are called for, merited by, or owed to it and hence that there are possibilities for characteristic failures of response or repudiations of the appeal that have no place in our relation to the agreeable things we consume. When Plato or Mary Mothersill claim an internal relation between beauty and love, ${ }^{22}$ this needn't be understood as either sentimentalizing or inflating the experience of the beautiful but rather as a recognition of the conceptual difference between something's being a value because it answers to my needs and recognizing something whose claim on me is independent of my needs, a value that my needs and desires are themselves answerable to. Part of what it means to say that "beauty inspires love" must be that the pleasure it causes is experienced as the recognition of a value to which my present interests and desires are themselves answerable or by which they are to be measured and hence a value that can create obligations (of attention, preservation, understanding, communicating, and so on). If a certain kind of pleasure can be said to inspire love, then that means that it now provides us with something it is possible to be true to or not, to betray or not, to keep faith with or not.

Both Kant and Proust want to identify something unconditional in the appeal of beauty. And we might see one aspect of the unconditional in the appeal of beauty that is shared by both Kant and Proust as emerging fairly directly from the distinction between the pleasure of the beautiful and the

22. "By beauty [as distinguished from the sublime], I mean that quality or those qualities in bodies by which they cause love, or some passion similar to it. . . . I likewise distinguish love, by which I mean that satisfaction which arises to the mind upon contemplating anything beautiful ... from desire ... which is an energy of the mind, that hurries us on to the possession of certain objects" (Edmund Burke, A Philosophical Enquiry into the Origin of Our Ideas of the Sublime and Beautiful [Oxford, 1990], p. 83). Alexander Nehamas's Only a Promise of Happiness came out as I was completing this paper, and, among its other virtues, his account both explores the conceptual connections between beauty and love and appeals to this connection by way of rejecting the claim for universal agreement. See Alexander Nehamas, "Beauty, Community, Universality," Only a Promise of Happiness: The Place of Beauty in a World of Art (Princeton, N.J., 2007), pp. 78-84. 
pleasure in the agreeable: the idea of a demand on the subject that is independent of one's current likes and dislikes. This is clear enough in Kant and is part of his definition of the autonomy of the beautiful. For Proust, we can begin by noting that the experiences he relates in passages like these are not descriptions of the gratification of some antecedently existing appetite for either hawthorns or the shifting appearances of trees as seen from a moving coach. Rather, the value they represent for him does not depend on their answering to his preexisting desires. Kant may sometimes write as if recognizing such a value were incompatible with the felt desire for the bearers of such values or required the suppression of such desire, but surely that is a mistake. The point is that the value in question and its claim upon me is recognized as not conditional on my having such desires. And, for both writers, the idea of something whose status as a value does not depend on my current desires or interests brings to the experience of that value a sense of my being measured by it (rather than my estimating it according to my own needs) and a normative direction of fit from oneself to the beautiful object rather than the reverse. The standard English translation of the German angenehm as "agreeable" is apt for expressing this contrast. For when there is failure of fit between my appetite and the food and drink I consume, we speak of it as "not agreeing with me," and with that the meal is dismissed, whereas when I am prepared to think of something as beautiful the question of my being in agreement or not with it is more centrally the question the aesthetic subject is faced with. Here the possibilities of failure of agreement are not limited to bringing the object into line with one's desire but can expand from disappointment in one's own responsiveness, to the sense of lost receptivity thematized for example in the odes to loss and dejection of William Wordsworth and Samuel Taylor Coleridge and on to Proust's deliberately hyperbolic description of himself as feeling "as wretched as though I had just lost a friend, had died myself, had broken faith with the dead or repudiated a God." (Where Kant joins Proust is in finding room in the idea of beauty for the possibility of being chastened or humbled by the experience, finding one's own response to it to be inadequate.)

The sense of a demand or requirement as characterizing the experience of the beautiful brings a dimension of normativity to the judgment of beauty that distinguishes it from both the ordinary empirical judgment of something as, for example, red and the more explicitly evaluative judgment of something as pleasant or agreeable. I have been arguing that this represents one of Kant's best insights about the beautiful, but I have also been suggesting that his particular ways of elucidating this dimension of normativity are unsuccessful, even within his own terms. In this paper I 
won't attempt to address with any adequacy the terms of Kant's positive account, but I do want to say something about two main lines of this account and what I see as unsatisfying about them. To begin with, it might be argued that we create an unnecessary air of mystery by speaking of something normative or demanding as issuing from the beautiful itself when it should be clear that the only genuine demand in question here is the one Kant explicitly insists on, namely, a demand coming from another person, that is, the demand for agreement with his judgment. Part of the problem with any response in these terms is that it doesn't help us understand what the source of this demand itself could be and how it could be, for Kant, the primary feature that distinguishes the judgment of beauty from the judgment of the agreeable. If we acknowledge that we do not demand such agreement with regard to what we find agreeable, even though as Kant also acknowledges we may have better reason to expect actual agreement there than in the case of the beautiful, then the particular demand for agreement contained in the judgment of the beautiful cannot be explained by reference to the normativity of either ordinary empirical judgments or declarations about genuine sources of pleasure. It must have some different basis, and the person making such a demand for agreement cannot understand himself to be backing this demand with the claim that he has, after all, identified a genuine source of pleasure here, one that you are obliged to share with him in enjoying. ${ }^{23}$ To refer the sense of requirement back to the person making a demand for agreement simply pushes back the question of why there should be any importance to agreement here that there is not with respect to our other pleasures and what it could be about this experience and the person's relation to it that puts him in a position from which he could make such a demand, a demand that another person would have any reason to respect. If we begin simply with one's experience of some kind of pleasure, something that is a perfectly free liking, then it is hard to see how adding to it a demand for universal

23.

But surely there is something strange here. In the case of the taste of sense, not only does experience show that its judgment (of a pleasure or displeasure we take in something or other) does not hold universally, but people, of their own accord, are modest enough not even to require others to agree (even though there actually is, at times, very widespread agreement in these judgments too). Now, experience teaches us that the taste of reflection, with its claim that its judgment (about the beautiful) is universally valid for everyone, is also rejected often enough. What is strange is that the taste of reflection should nonetheless find itself able (as it actually does) to conceive of judgments that can demand such agreement, and that it does in fact require this agreement from everyone for each it its judgments. [C], $\$ 8$, p. 58] 
agreement can by itself contribute any special normativity to the situation or bring us closer to the concept of the beautiful. So far it remains simply a pleasure of mine to which I have added the otherwise unmotivated requirement that others agree with me.

In response to such difficulties, some commentators on Kant wish to show that the imperatival character of the judgment of beauty is in fact dispensable in Kant and does not in fact mark anything distinct from the normativity of ordinary empirical judgments. ${ }^{24}$ My own view is that Kant is right in this, as well as in agreement with Proust, in finding a sense of necessity or demand with respect to the beautiful that is not found with respect to either the agreeable or ordinary empirical judgments. However, he mislocates it in the demand for universal agreement, in part because necessity and universality are so deeply conjoined for him. (The passages from Proust and the relations between the experience of beauty and the necessities of love are meant to remind us that not all necessities take that universal form.) Kant is clear that something normative needs to underwrite the demand for universal agreement, and he is also clear that no sense of requirement can be derived simply from the goodness of pleasure itself. That is, if I demand universal agreement in the pleasure I take in something, my reason cannot be that otherwise you would be missing out on a true source of pleasure, which is a genuine good. However heartfelt, any recommendation of that sort may legitimately be dismissed, either because you doubt that we do take pleasure in the same things or because you are perfectly satisfied with the sources of pleasure with which you are already familiar. You may not doubt me about my own pleasure or that I have identified a possible source of pleasure for you, yet you may still find that all this has no claim upon you. And, perhaps more importantly from Kant's own perspective, nothing of that character could explicate the sense of requirement in the judgment of beauty since, as he puts it, "an obligation to enjoy oneself is a manifest absurdity" ( $C J, \$ 4, \mathrm{p} .50 \mathrm{n} .17)$.

It is, I think, because his original distinction between the agreeable and the beautiful is characterized in terms of a sense of obligation or requirement attaching to the one but not the other (something I'm claiming is shared by Proust) and because he recognizes the need for an account of its

24. Compare to Mothersill: "That idea is strongly counter-intuitive. Nothing would be lost if judgments were treated as assertions (or declarative sentences), as candidates for truth," and "in short, the idea of an aesthetic imperative seems a liability to Kant's theory from every point of view" (Mothersill, Beauty Restored, pp. 211, 218). Note that she is disagreeing with Kant here and not with the "normative" or imperatival interpretation of Kant. Throughout this paper I am trying to tease out what is correct in Kant's appeal to a normative element in the judgment of beauty that is additional to the norms for correct empirical judgment quite generally (for example, color judgments). Such judgments can still for all that be candidates for truth. 
basis that throughout the Critique of Judgment he makes various attempts to locate the source of this normativity somewhere or other, primarily and predictably in the demands of morality. So, for instance, he argues that we require that all others take disinterested pleasure in the beauty of the natural world because the capacity to do so makes us more fit for the moral life (see CJ, \$40, pp. 159-62). Or alternatively it may be that a capacity for disinterested pleasure is at least a reliable sign of moral sensitivity and hence to be welcomed and approved of (even, that is, if we are unsure of its independent contribution to good moral character) (see CJ, \$42, pp. 16570). Or, in a different register, Kant will suggest that the possibility of our finding beauty in the world encourages us in our faith that pure practical reason can actually be effective in the empirical world because the experience of beauty intimates that we are in some sense, after all, made for each other, fitted to each other's requirements (see $C J$, $\$ \$ 42,57$, pp. 165-70, 211-20). And taking these and other considerations together may bring us to the idea that beauty is in fact a symbol of morality (see $C J$, \$59, pp. 225-30). I will make no attempt to do justice to these large questions, and although I am skeptical about this entire line of thought I will not defend that skepticism here beyond mentioning my sense that the very diversity and inconclusiveness of the relations Kant suggests between beauty and morality indicates to me that they have a tentative or at least unresolved status in his overall argument. However, even if no objection is made to any of the claims just mentioned, either individually or collectively, I think it can be argued that even their truth would not provide us with an answer to the question that Kant originally posed for us.

For that was a question about the normative force of a claim in response to a particular experience of beauty, a normative dimension that is distinct from the normativity of an ordinary empirical judgment or the recommendation to avail oneself of a source of pleasure. And the sense of requirement associated with this particular experience of something beautiful cannot be explicated by reference to a quite general obligation to cultivate one's capacity for disinterested pleasures (so as to provide "a transition from sense enjoyment to moral feeling” [CJ, \$41, p. 164]). This was our original problem, the special normative dimension of the singular judgment of beauty and how it could underwrite the demand for universal agreement, even though Kant is equally insistent that the pleasure in question is a perfectly "free liking" and that any such agreement could not be required by reference to concepts or principles. We would not be closer to understanding this even if we were convinced by Kant's claim of the "Intellectual Interest in the Beautiful" that "to take a direct interest in the beauty of nature (not merely to have the taste needed to judge it) is always 
a mark of a good soul; and that, if this interest is habitual, if it readily associates itself with the contemplation of nature, this [fact] indicates a mental attunement favorable to moral feeling" ( $C J, \$ 42$, pp. 165-66). And this is because, for Kant, any judgment of taste, whether of the beautiful or the agreeable, is a singular judgment, and hence whatever normativity characterizes it and distinguishes it from the agreeable cannot be understood by reference to the moral recommendation to cultivate a sensibility for pleasure and judgments of that general type..$^{25}$

I would also argue that the appeal to morality suggests the wrong role for agreement in the experience of beauty and the wrong importance for it. There are obvious reasons concerned with the nature of morality why the very demandingness of the moral should be understood in terms of the conditions for securing agreement between people. Moral and political conflicts are a fact of life and can exact a terrible price on the contenders involved because they have to live together and find ways to respect and make comprehensible the demands they make on each other. While it is true that our different experiences of beauty can be painful or alienating in certain circumstances, they do not demand resolution and agreed-upon terms of fair agreement before civil life can resume. ${ }^{26}$ And we differ in our experiences of the agreeable as well, though as Kant notes, in these contexts we are "modest enough not to require others to agree" $(C J, \$ 8, \mathrm{p} .57)$, even when we are aware that, in fact, actual agreement about the agreeable is often more widespread than agreement about the beautiful. It seems that it could only be our different attitude toward the beautiful itself that could account for why we should ever treat our experiences of the beautiful any differently, taking that additional step when we know it is likely to be repudiated. But that, I've been suggesting, requires detaching the demand for agreement from the sense of necessity or requirement in the experience itself.

If Proust's narrator can understand himself to be making a vow of some sort to his hawthorns, what he is doing is meant to place himself under an obligation, something like the vow to remain responsive to this beauty

25. "It is a fact that any judgment of taste is always a singular judgment about the object" $(C J, \$ 33$, p. 148). "That is also why all judgments of taste are singular judgments, because they do not connect their predicate, the liking, with a concept but with a singular empirical presentation that is given" (CJ, $\$ 37$, p. 154).

26. Compare John Rawls: "A second contrast between the right and the good is that it is, in general, a good thing that individuals' conceptions of their good should differ in significant ways, whereas this is not so for conceptions of right. ... Moreover, there is no urgency to reach a publicly accepted judgment as to what is the good of particular individuals. The reasons that make such an agreement necessary in questions of justice do not obtain for judgments of value" (John Rawls, A Theory of Justice [Cambridge, Mass., 1999], p. 393). 
because it defines him. This is a kind of imperative addressed to himself, but it is something different from a demand for universal agreement. In making a vow to the hawthorns and promising that he will be true to them in spite of the pleasures and distractions of "paying calls and listening to silly talk," he is both affirming the superior value of the hawthorns and attempting to bind himself to that value. He feels the binding is necessary not only because of the temptations of gossiping in the city but because he feels that the appeal of the hawthorns, however intense, is nonetheless something fragile, and, that were he to lose his responsiveness to this appeal, it would count as a loss of the self he presently is and cares about. By contrast, the experience of the agreeable does not carry with it a similar threat. With respect to something agreeable, to lose one's desire for it is typically to find something else more agreeable or equally so and move on. There need be no experience of the loss of some part of oneself and hence nothing to mourn or regret in this change of tastes. Marcel does not measure himself against his responsiveness to the agreeable, and he doesn't make vows to their objects because the possibility of ceasing to find them a source of pleasure is not something he needs to preserve himself against, because that possibility is not experienced as any kind of failure on his part. Within the general economy of the agreeable, if I am tempted by something else that distracts me from my original desire, I have no reason, apart from prudential or moral considerations extrinsic to the desire itself, not to follow what happens to please me more and abandon what no longer pleases me as much. Binding oneself against loss or lapse is not called for, and therefore there is no sense to a vow of any kind. With respect to the beautiful, however, he claims a value in continuing to cherish this object, continuing to be responsive to its appeal, which is over and above the value of the pleasure it presently gives him and may survive it. In regarding the beautiful or an object of love, there is room for the idea of failure in the possibility of the abandonment or replacement of one's desire, the prospect of which is experienced as a threat to the self. It is this threat that Marcel shrinks from when Swann suggests to him that if he moved away from France and formed other attachments he would not be tormented by Gilberte or other unattainable objects of his desire. But the prospect of other attachments, along with the forgetting of his current ones and thus the relief from the suffering they are now causing him are not seen by him as any form of compensation for or solution to his current sufferings but only as adding to them. Swann is here representing the perspective of an enlightened egoistic hedonism, according to which the elimination of an unfulfilled longing can count in the same way as a satisfied desire in the economy of pleasure. Marcel recognizes a certain hedonic rationality in 
this perspective, and he feels the claim of what he calls his "better judgment" here, ${ }^{27}$ and yet he recoils from Swann's suggestion as entailing the obliteration of the self whose future well-being could matter to him in the first place. The abandonment recommended by Swann and the perspective of the rational management of the agreeable is regarded by him with dread:

this dread, far from being dissipated, is intensified, if to the pain of such a privation we feel that there will be added what seems to us now in anticipation more painful still: not to feel it as a pain at all-to remain indifferent; for then our old self would have changed ... it would be in a real sense the death of the self, a death followed, it is true, by resurrection, but in a different self, to the love of which the elements of the existing self that are condemned to die cannot bring themselves to aspire. [BG, p. 340]

Both Kant and Proust could say that Marcel knows his experience of beauty presents him with something in the form of a normative demand that is not contained in the experience of the agreeable because it is the beautiful and not anything he finds merely agreeable (and this is the whole force of the "mere" in this context) that presents him with the possibility of something he might fail or stray from. And for both of them in response to the beautiful, acknowledging the possibility of characteristic forms of failure of response means acknowledging oneself as subject to something with the force of a requirement. Many writers have wanted to describe the encounter with beauty in terms of the claim of something outside the world of egoistic desire and in this way provide a place for the ideas of objectivity, impersonality, and universality as applied to beauty. This is only partly Kant's way. He shares the sense of the concept of beauty being reserved for something outside of and imposing itself upon egoistic desire

27.

And yet my ... better judgment whispered: "What difference can that make, since you won't be distressed by it? When M. Swann tells you that you won't come back he means by that that you won't want to come back, and if you don't want to that is because you'll be happier out there." For my judgment was aware that Habit ... undertakes as well to make dear to us the companions whom at first we disliked, to give another appearance to their faces, to make the sound of their voices attractive, to modify the inclinations of their hearts. It is true that these new friendships for places and people are based upon forgetfulness of the old; but my reason precisely thought that I could envisage without dread the prospect of a life in which I should be for ever separated from people all memory of whom I should lose, and it was by way of consolation that my mind was offering to my heart a promise of oblivion which succeeded only in sharpening the edge of its despair. [BG, p. 339] 
and hence as being impersonal or at any rate transpersonal in its meaning. And while he does, of course, seek to join this to a claim to universality, he differs from other writers on beauty in seeking to maintain such universality while, for principled reasons, denying that beauty is any kind of objective property of things (not even of the sort belonging to secondary qualities such as colors). This is indeed his central paradox..$^{28}$ Without claiming that Proust solves this paradox, we can see that he draws our attention to a dimension of the aesthetic that fits better with the logical form of the kind of claim Kant wants to make for beauty, while avoiding the internally problematic features of demands for universal agreement, even universal enjoyment that can't be met on his own terms, whether because pleasure, like any other affect, cannot coherently be commanded, or because "an obligation to enjoy oneself is a manifest absurdity" ( $C J$, $\$ 4$, p. 50 n. 17), or because the autonomy of the judgment of taste obliges anyone in possession of the concept of that kind of judgment to dismiss any such demand for "approval by any interest, whether of sense or of reason” (CJ, \$5, p. 52). Proust will agree with Kant that an invocation of necessity is needed to carve out the concept of the beautiful from the indifferent mass of the merely agreeable and consumable. But instead of the juridical, legislating context favored by Kant here and elsewhere, Proust is concerned instead with the necessity whose source is the thing itself in front of him, the one that has arrested his attention.

28. See Ginsborg, "Kant on the Subjectivity of Taste," in Kant's Aesthetics, ed. Herman Parret (Berlin, 1998) for an especially helpful discussion of this paradox and Kant's principled reasons for denying that beauty can have the kind of objectivity of any ordinary property. I have profited from this paper in several ways. 